\title{
Role of purinergic signalling and proinflammatory cytokines in diabetes
}

\section{ABSTRACT}

Extracellular purines activate $\mathrm{P} 1$ adenosine receptors and $\mathrm{P} 2$ nucleotide receptors. These receptors are present on the pancreatic islet cells as well as on hepatocytes, adipocytes, pancreatic blood vessels and nerves. ATP is released together with insulin from $\beta$-cell granules in response to a rapid decrease in blood glucose levels. The ATP-dependent $\mathrm{P} 2 \mathrm{X}$ receptor activation on pancreatic $\beta$-cells results in a positive autocrine signal and subsequent insulin secretion. Adenosine, through activation of $\mathbf{P 1}$ receptors present on adipocytes and pancreatic islet cells, inhibits the release of insulin. Adenosine activates $A_{2 B}$ receptors thereby stimulating production of IL- 6 and other cytokines, which increases insulin resistance. Interleukin- 6 also plays an important role in diabetes. In type 2 diabetes and obesity, the long-term increase of IL- 6 concentration in blood above $5 \mathrm{pg} / \mathrm{mL}$ leads to the chronic and permanent increase in expression of SOCS3, contributing to the increase in insulin resistance in cells of the skeletal muscles, liver and adipose tissue. In diabetes there is an increased synthesis and release of pro-inflammatory cytokines, which cause the damage of the pancreatic islet cells, and in type 2 diabetes cause the development of insulin resistance. Ecto-enzymes metabolizing nucleotides are involved in the termination of the nucleotide signalling pathway and play the key role in regulation of extracellular ATP concentration. Ecto-NTPDases in cooperation with 5'-nucleotidase may significantly increase ectoadenosine concentration. NTPDase 3 activity has only

Address for correspondence:

dr n. med. Marek Cieślak

Gabinet Neurologiczny Marek Cieślak

ul. Kozacka 5A m.18/19, 87-100 Toruń

e-mail: marcies@autograf.pl

Transtation: lek. Małgorzata Kamińska

Clinical Diabetology 2017, 6, 3, 90-100

DOI: $10.5603 /$ DK.2017.0015

Received: 23.07.2016

Accepted: 29.06.2017 been demonstrated on Langerhans cells. NTPDase3 may influence the secretion of insulin by hydrolysing adenine nucleotides. In diabetes the pro-inflammatory cytokines such as interleukin $1 \beta$ (IL-1 $\beta$ ), tumour necrosis factor- $\alpha$ (TNF- $\alpha$ ) and interferon- $\gamma($ IFN- $\gamma$ ), as well as pancreatic derived factor PANDER are involved in the apoptosis of pancreatic $\beta$-cells. This causes disturbance of the balance between pro-inflammatory and protective cytokines. We believe that neutralization of pro-inflammatory cytokines, especially interleukin $1 \beta$, with the IL-1 receptor antagonist (IL-1Ra) and/or IL-1 $\beta$ antibodies might cause the reduction of the inflammatory process in pancreas islets, normalize concentration of glucose in blood and decrease the insulin resistance. (Clin Diabetol 2017; 6, 3: 90-100)

Key words: diabetes mellitus, nucleotides, adenosine, purinergic receptors, ecto-nucleotidases, proinflammatory cytokines

\section{Introduction}

Pathophysiological disorders in diabetes consist of abnormal glucose metabolism and transport, which is a consequence of inadequate insulin secretion. These disorders lead to hyperglycaemia, the formation of free fatty acids (FFAs) and the release of proinflammatory cytokines. In diabetes, metabolic disorders not only affect the pancreas, but also other organs such as the liver, skeletal muscles and adipose tissue. Pathological processes include: disorders of cardiovascular, urinary and gastrointestinal systems as well as abnormal skin healing, sexual dysfunction and muscle weakness. Usually, diabetes complications, such as micro- and macroangiopathy, retinopathy and polyneuropathy, appear within a few years after establishing the diagnosis of diabetes, but sometimes they develop before the disease is detected. Type 1 diabetes (T1D), an insulindependent disease, is an autoimmune disease that 


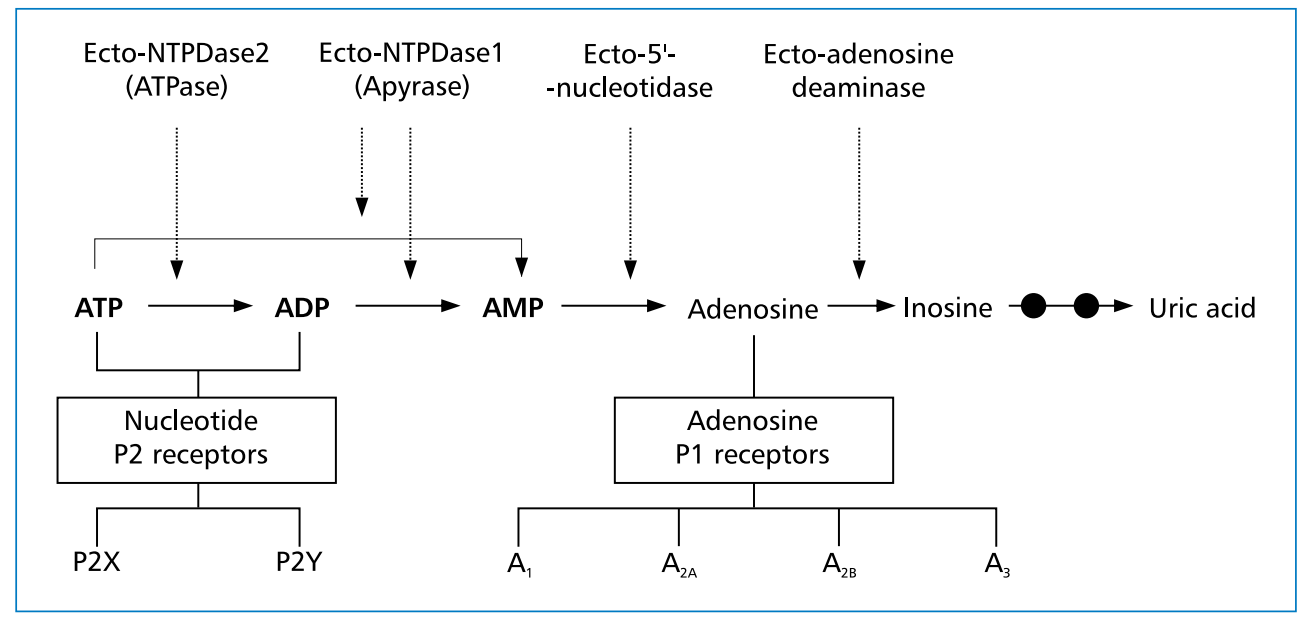

Figure 1. Metabolism of ecto-nucleotides and adenine nucleosides and types of purinergic receptors

becomes clinically apparent due to environmental factors, especially viral infections, in patients with genetic predisposition [1, 2]. Symptoms of diabetes appear when about $80 \%$ of $\beta$-cells are damaged. The course of the disease is characterized by a progressive decrease in the number of pancreatic cells and deterioration of their function, and patients require administration of exogenous insulin. There are various factors, especially proinflammatory cytokines, responsible for $\beta$-cell damage during the course of diabetes. In type 2 diabetes (T2D), insulin secretion may be almost normal at first, but insulin resistance is clearly present [1, 2]. Type 2 diabetes is usually characterized by a later onset, often accompanied by obesity, a considerable autoinflammatory process in pancreatic islets, a low-grade inflammation of adipocytes and increased insulin resistance of hepatocytes and skeletal muscle cells [1, 2]. It is thought that obesity itself causes an increase in the level of proinflammatory cytokines in the blood [3]. Similarly, hyperglycaemia promotes cytokine secretion, which was demonstrated in human endothelial cell culture [4]. The mechanisms responsible for insulin resistance include: oxidative stress, endoplasmic reticulum stress, amyloid deposits in pancreatic islets, accumulation of ectopic lipids in muscles, liver and pancreas, and processes such as lipotoxicity and glucotoxicity [3, 5-7]. Oxidative stress and endoplasmic reticulum stress lead to increased intra-cellular production of proinflammatory cytokines, thus inducing inflammatory processes $[8,9]$. In diabetes, the pancreas is infiltrated by immune cells, such as macrophages, which are also the source of pro-inflammatory cytokines.

Purinergic receptors were first defined in 1976 and two years later they were divided into P2 receptors, which are activated by adenine nucleic acids (ATP and
ADP) and pyrimidines (UTP and UDP) and P1 receptors, which are activated specifically by adenine. Additionally, $\mathrm{P} 2$ receptors were subdivided into $\mathrm{P} 2 \mathrm{X}$ ionotropic receptors and metabotropic $P 2 Y$ receptors, whereas $P 1$ receptors were subdivided into $A_{1}, A_{2 A}, A_{2 B}$ and $A_{3}$ subtypes. Adenosine $A_{1}$ and $A_{3}$ receptors are $G_{i}$-proteindependent and inhibit adenylate cyclase, whereas $A_{2 A}$ and $A_{2 B}$ receptors are $G_{s}$ - and $G_{0}$-protein-dependent receptors stimulating cyclic adenosine monophosphate (AMP) formation [1, 2]. The presence of seven subtypes of $\mathrm{P} 2 \mathrm{X}$ receptors and eight subtypes of $\mathrm{P} 2 \mathrm{Y}$ receptors have been demonstrated $[1,2]$. Most $P 2 Y$ receptors are $\mathrm{G}_{\mathrm{q}}-\mathrm{G}_{11}$-dependent and they activate $\mathrm{C}-\beta$ phospholipase (PLC- $\beta$ ), except for $\mathrm{P}_{2} \mathrm{Y}_{12}, \mathrm{P}_{2} \mathrm{Y}_{13}$ and $\mathrm{P}_{2} \mathrm{Y}_{14}$ receptors, which are $\mathrm{G}_{\mathrm{i}}$-dependent and inhibit adenylate cyclase, and $P 2 Y_{11}$ receptor, which is $G_{s}$ - and $G_{q}$-dependent $[1,2]$. Enzymes such as ecto-nucleoside triphosphate diphosphohydrolases (NTPDases) degrade adenine nucleotides (ATP and ADP) to AMP, and then AMP is transformed into adenosine by 5 '-nucleotidase. In the presence of adenosine deaminase (ADA) adenosine is converted to inosine, and/or in the presence of adenosine kinase (AKA) belonging to the ribokinase family it is converted by phosphorylation into 5'-AMP. The activity of the following enzymes: NTPDase1, NTPDase2, NTPDase 3 and 5'nucleotidease was demonstrated on human and animal endocrine and exocrine pancreatic cells and blood vessels (Fig. 1) [10-12].

Pathological processes in diabetes are mediated by purines and cytokines. In type 2 diabetes, these compounds promote insulin resistance, which is the main factor responsible for the progression of the disease. Among purines, ATP is of particular importance, because it activates the $P 2 X_{3}$ receptor present on the $\beta$-cells, which generates a positive autocrine signal 
resulting in insulin secretion. Adenosine, by activating A receptors differently than ATP, inhibits insulin secretion and, together with ADP and 5'-AMP, stimulates the secretion of glucagon. Proinflammatory cytokines interleukin $1 \beta$ (IL-1 $\beta$ ), tumour necrosis factor- $\alpha$ (TNF- $\alpha$ ) and interferon- $\gamma$ (IFN- $\gamma)$ - have proapoptotic effect on $\beta$-cells. These cytokines cause decrease in insulin secretion and reduction in the amount of pancreatic $\beta$-cells.

\section{The influence of ATP and purinergic receptors of $\beta$-cells on insulin secretion}

ATP affects the secretion of insulin through the intracellular mechanism and extracellular activation of the $\mathrm{P} 2$ receptors present on the $\beta$-cell surface [13]. Since ATP is produced intracellularly by the glycolysis and by the mitochondrial oxidative process, mitochondrial dysfunction of $\beta$-cells causes a reduction in the production and release of ATP and insulin. At the cellular level, mitochondrial dysfunction is primarily responsible for the progression of diabetes. Various intracellular pathways are involved in the secretion of insulin from the $\beta$-cells, which are affected by ATP in the first phase of the process [14]. ATP increases insulin secretion by activation of $\mathrm{P} 2 \mathrm{X}$ and $\mathrm{P} 2 \mathrm{Y}$ receptors present on $\beta$-cells, and the effect of ATP is dependent on blood glucose [15-17]. Studies on animals have demonstrated the presence of the following $\mathrm{P} 2 \mathrm{X}$ receptors: $\mathrm{P} 2 \mathrm{X}_{1}, \mathrm{P} 2 \mathrm{X}_{2}, \mathrm{P} 2 \mathrm{X}_{3}, \mathrm{P} 2 \mathrm{X}_{4}$, $\mathrm{P} 2 \mathrm{X}_{6}$ and $\mathrm{P} 2 \mathrm{X}_{7}[12,18-20]$. There are contradictory reports on the presence of the purinergic receptors in humans. The presence of $\mathrm{P} 2 \mathrm{X}_{1}, \mathrm{P} 2 \mathrm{X}_{2}, \mathrm{P} 2 \mathrm{X}_{4}$ and $\mathrm{P} 2 \mathrm{X}_{6}$ receptors (detected in rats) $[19,20]$, has not been confirmed so far. Currently, there are no doubts about the presence of the following receptors on human $\beta$-cells: $\mathrm{P} \mathrm{X}_{3}$ (immunocytochemistry detected), $\mathrm{P}_{2} \mathrm{X}_{5}[1$, 2], $\mathrm{P}_{2} \mathrm{X}_{7}[1,2], \mathrm{P} \mathrm{Y}_{11}$ (RT-PCR, Western blot analysis, immunofluorescence detected) [21], P2Y 12 (RT-PCR, Western blot analysis, immunofluorescence detected) [21]. The source of extracellular ATP is both exocytosis of ATP from $\beta$-cell granules and release from the pancreatic nerve endings [17, 22]. It was found in 1975 that ATP and insulin are secreted together by exocytosis from pancreatic $\beta$-cell granules [23]. One year later it was demonstrated that ATP stimulates glucagon and insulin secretion, and that this process is dependent on blood glucose [24]. At high blood glucose levels, P2X receptor antagonists cause a $65 \%$ decrease in insulin secretion [19]. Cellular granules containing insulin also contain ATP and ADP, and their release is regulated by activation of the heterologous $\mathrm{P} 2 \mathrm{X}_{2}$ receptor present on $\beta$-cells [25]. In addition, other molecules, such as 5-hydroxytryptamine, gamma-aminobutyric acid, glutamates and zinc, are released along with ATP, and these molecules may affect insulin secretion by autocrine mechanism, similarly to ATP $[19,20,25]$. In rats, activation of $\mathrm{P} 2 \mathrm{X}$ receptors on pancreatic $\beta$-cells results in transient increase in insulin secretion, even at low glucose concentrations [17]. Under physiological conditions, the $\mathrm{P} 2 \mathrm{X}_{7}$ receptor does not participate in $\beta$-cell metabolism, since activation of this receptor occurs only at high concentrations of ATP, above $100 \mu \mathrm{M}$. $\mathrm{P} 2 \mathrm{X}_{3}$ receptors are particularly important in humans. $\mathrm{P} 2 \mathrm{X}_{3}$ receptor activation generates a positive autocrine signal (autocrine feedback loop) and its amplification, which results in insulin secretion [19]. In response to the rapid decrease in blood glucose, ATP released along with insulin from $\beta$-cell granules activates the $\mathrm{P}_{2} \mathrm{X}_{3}$ receptor, which causes an increase in intracellular $\mathrm{Ca}^{2+}$ concentration and thereby amplifies insulin release.

Numerous $\mathrm{P} 2 \mathrm{Y}$ receptors are present on pancreatic $\beta$-cells. Previous studies on animal models did not provide a clear answer as to the role of P2 receptors in insulin secretion. In 2001 Fernandez-Alvarez et al. demonstrated for the first time in humans that $\mathrm{P} 2$ receptor agonists cause increased insulin secretion [26]. Studies of pancreatic cancer cells (insulinoma) showed the presence of $\mathrm{P} 2 \mathrm{Y}$ receptors such as $\mathrm{P} 2 \mathrm{Y}_{1}, \mathrm{P}_{2} \mathrm{Y}_{2}, \mathrm{P}^{2} \mathrm{Y}_{4}$ $\mathrm{P}_{2} \mathrm{Y}_{6}, \mathrm{P}_{2} \mathrm{Y}_{11}, \mathrm{P}_{2} \mathrm{Y}_{12}$ and $\mathrm{P} 2 \mathrm{Y}_{13}$ [18]. Currently, we do not know the effects of activation of most of these receptors, and there are significant differences in their presence between different species of animals. $\mathrm{P} 2 \mathrm{Y}_{11}$ and $P 2 Y_{12}$ receptors $[1,2,27]$ have been shown on human pancreatic $\beta$-cells. Some reports indicate that activation of $\mathrm{P} 2 \mathrm{Y}$ receptors by adenine nucleotides may increase or decrease insulin secretion, depending on the type of receptor. However, there is predominant opinion that activation of $\mathrm{P} 2 \mathrm{Y}$ receptors increases glucose-induced insulin secretion. In particular, activation of the $\mathrm{P}_{2} \mathrm{Y}_{4}$ receptor stimulates the secretion of insulin irrespective of blood glucose [18]. It has been shown that activation of $\mathrm{P}_{2} \mathrm{Y}_{1}$ and $\mathrm{P}_{2} \mathrm{Y}_{6}$ receptors inhibits insulin secretion at high blood glucose levels [28]. Another study on these receptors showed that the activation of $\mathrm{P}_{2} \mathrm{Y}_{1}$ and $\mathrm{P}_{2} \mathrm{Y}_{6}$ receptors stimulated insulin secretion at glucose concentrations above $8 \mathrm{mM}$ [29]. In mice, ADP may both inhibit insulin secretion by $\mathrm{P} 2 \mathrm{Y}_{13}$ receptor activation and induce this process by activating the $\mathrm{P} 2 \mathrm{Y}$, receptor [30]. It is supposed that the ADP-activated $P 2 Y_{1}$ receptor plays a key role in the insulin secretion by $\beta$-cells [11, 31]. It seems likely that the treatment with ATP and ADP analogues will increase the secretion of insulin and, in consequence, decrease glycaemia.

\section{The role of adenosine and $\mathbf{P} 1$ receptors in diabetes}

Adenosine activates four subtypes of $G$ protein-dependent receptors $\left(A_{1}, A_{2 A}, A_{2 B}\right.$ and $\left.A_{3}\right)$ [32]. The 
presence of adenosine receptors $A_{1}$ and $A_{2 B}$ has been shown on pancreatic $\beta$-cells, although the role of these receptors in insulin secretion is unclear [12, 33-37]. Adenosine inhibits the secretion of insulin and, along with ADP and 5'-AMP, stimulates the secretion of glucagon [38, 39]. Stimulation of glucagon secretion by adenosine and lack of such effect on secretion of insulin suggest that $\alpha$-cells are more sensitive to adenosine than $\beta$-cells. Töpfer et al. have demonstrated that administration of $\mathrm{A} 1$ receptor agonists results in increased insulin sensitivity and a decrease in free fatty acids and triglycerides [40]. Activation of the $A_{1}$ receptor by selective and non-selective agonists reduces insulin secretion [40]. Experimental studies on animals have shown that activation of $A_{1}$ receptors causes significant side effects, which result from the activation of these receptors present in the heart and blood vessels, which considerably limits the use of these receptors for the treatment of diabetes [41]. Side effects include hypotension and bradycardia, decreased atrial contractility, impaired renal function, and the release of neurotransmitters. Activation of $A_{1}$ receptor present on adipocytes results in inhibition of adenylate cyclase, decreased levels of cyclic adenosine monophosphate (cAMP), suppression of protein kinase A and, consequently, inhibition of lipolysis. In 1972, Fain et al. found that adenosine and adenosine analogues acted antagonistically to catecholamines, which stimulate CAMP formation and thereby induce lipolysis in adipocytes [42]. In 1961, Dole has demonstrated in rats that adenosine and some of its metabolites inhibit the conversion of triglycerides (TGs) to FFA [43]. Previously, this was suggested by the studies performed by Schwabe who found that the addition of adenosine deaminase to fat cell culture supressed lipolysis [44, 45]. Dhalla et al. have described the presumed mechanism of suppressing lipolysis by adenosine [41].

It is suspected that the inhibition of lipolysis in adipocytes is indirectly mediated by $A_{1}$ receptor activation, resulting in inhibition of adenylate cyclase, followed by a decrease in CAMP concentration. In turn, the decline in CAMP levels inhibits protein kinase A (PKA), and this enzyme supresses lipases, such as hormone-sensitive lipase (HSL) and adipose triglyceride lipase (ATGL). This process leads directly to the suppression of triglyceride conversion into free fatty acids [41]. We suppose that the pharmacological inhibition of lipolysis aimed at lowering blood levels of free fatty acids may be an effective treatment for type 2 diabetes. Dipyridamole, a medication used in cardiovascular diseases, inhibits adenosine reuptake and lowers blood glucose, free fatty acids and triglycerides [46]. Studies on various $A_{1}$ receptor agonists are performed in order to search for potential antilipidaemic agents, and some of these compounds are considered for clinical trials. Among the $A_{1}$ receptor agonists that have been studied in the past or are currently under investigation are: SDZ WAG-994 (N-cyclohexyl-2'-O-methyladenosine), GR79236 (N [(1S, 2S)-2-hydroxycyclopentyl]-adenosine) and others such as ARA and CVT-3619 [41]. These compounds inhibit lipolysis in adipocytes, effectively lowering blood levels of free fatty acids and glucose.

Adipose tissue produces proinflammatory compounds, such as interleukine-6, C-reactive protein (CRP) and plasminogen activator inhibitor 1 (PAl-1), which increase tissue resistance to insulin $[47,48]$. Adenosine activates $A_{2 B}$ receptors and thereby contributes to increased insulin resistance by affecting the production of IL- 6 and other cytokines. Animal studies confirm that $A_{2 B}$ receptor activation increases serum IL-6 levels $[49,50]$. Surprisingly, study results suggest that IL- 6 may both be involved in the development of insulin resistance and improve insulin sensitivity [51, 52]. In type 2 diabetes, activation of AMP-activated protein kinase (AMPK) and the involvement of such molecules as leptin, SOCS3 and SOCS1 (suppressor of cytokine signalling) increases insulin resistance, which is responsible for the disease progression [52-54]. Chronically elevated IL-6 levels increase SOCS3 and SOCS1 protein expression, contributing to increased insulin resistance in skeletal muscles, liver and adipose tissue. Under physiological conditions, e.g. after exercise, the concentration of IL-6 in the blood increases significantly and then returns to baseline level in a short time. Such sudden and short-term increase in IL- 6 levels does not lead to an increase in SOCS3 expression, but increases insulin sensitivity [52]. Thus, it is desirable to obtain a short-term increase in IL-6 levels (e.g. by moderate exercise) in order to maintain normal peripheral tissue sensitivity to insulin [52]. Contrary to this, the long-term increase in IL- 6 levels that occurs in type 2 diabetes and obesity leads to chronic and persistent increases in SOCS3 expression [52].

Since adenosine $A_{2 B}$ receptors are involved in macrophage activation, it is supposed that the activation of these receptors affects the inflammatory process of adipose tissue and the development of insulin resistance. Recently published results from the studies of

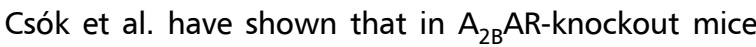
$\left(A_{2 B} R^{-/-}\right)$macrophages activated via alternative way are lacking some transcription factors such as CCAAT (enhancer binding protein $\beta$, interferon regulatory factor 4 and peroxisome proliferator-activated receptor $\beta$ ) [48]. In addition, in vitro studies have shown that $A_{2 B}$ receptor activation suppresses those inflammatory and metabolic processes in macrophages that involve free fatty acids. 
Adenosine, through activation of $A_{2 B}$ receptors, contributes to increased insulin resistance by the influence on the production of IL- 6 and other cytokines. Activation of $A_{2 B}$ receptors results in increased serum IL-6. It is supposed that in patients with diabetes administration of adenosine antagonists and adenosine degradation by adenosine deaminase may reduce insulin resistance in skeletal muscles $[55,56]$. The results of studies by Figler et al. suggest that $A_{2 B}$ receptors blockade may be an effective way to manage insulin resistance by reducing hepatic glucose production (HGP) and by reducing the formation of IL-6 and other cytokines [57].

Adenosine in the extracellular space affects the transport of glucose into striated muscle cells; in myocardiocytes and adipocytes it increases the insulin-stimulated glucose transport into the cells. The conversion of adenosine to inosine by adenosine deaminase or blockade of adenosine by adenosine receptor antagonists (CPDPX, 8-cyclopentl-1,3-dipropylxanthine) results in a decrease in insulin-stimulated glucose transport in skeletal muscles [58]. This process may be induced by the reduction of the number of GLUT4 transporters on the surface of the cells and/or the decrease in the activity of these transporters in the glucose transport into cells. Reduced expression of glucose transporters on the surface of cells is strictly responsible for decreased effectiveness of insulin in glucose transport into skeletal muscle cells and adipocytes, which contributes to the development of insulin resistance [58, 59]. Han et al showed that adenosine affects contractionstimulated glucose transport and/or insulin-stimulated glucose transport [58].

\section{The role of ecto-enzymes in diabetes and} their potential therapeutic usefulness

The activity of enzymes involved in the metabolism of nucleotides has been demonstrated on pancreatic islet, follicular and ductal cells as well as in blood vessels. Ecto-nucleoside triphosphate diphosphohydrolases (NTPDases) present on the surface of these cells play a crucial role in nucleotide transformation. So far, four E-NTPDases present on the cytoplasmic membrane have been cloned, differing in location and properties: NTPDase1 (apyrase/CD39), NTPDase2, NTPDase3 and NTPDase8 [60,61]. In humans, NTPDase1 activity was observed on acinar cells and in blood vessels and capillaries within the pancreas. NTPDase2 activity has been demonstrated on follicular cells, on cells surrounding pancreatic islets and in capillaries. NTPDase 3 activity was demonstrated only on the cells of islets of Langerhans. High activity of NTPDases has been demonstrated in patients with type 2 diabetes [62]. No 5'-nucleotidase activity was observed on pancreatic islet cells, and such activity has been demonstrated only in the capillaries within the Langerhans islets [11, 63]. NTPDase1 hydrolyses both ATP and ADP, NTPDase 2 hydrolyses ADP, and NTPDase3 is characterized by intermediate profile of action (hydrolysis) [61]. Hydrolysis of ATP and ADP results in the formation of AMP, which is converted to adenosine by 5 '-nucleotidase.

NTPDase1 involvement in insulin secretion has been confirmed by the results of studies in which the administration of apyrase inhibitor ARL67156 resulted in increased insulin secretion [64-66]. Thus, apyrase reduces insulin secretion by extracellular degradation of ATP and ADP, but it also participates, together with 5 '-nucleotidase, in formation of adenosine, which probably slightly inhibits insulin secretion through activation of P1 receptors. The surprising reports of Jacques-Silva et al. suggest that the conversion of adenosine to inosine by adenosine deaminase does not influence the effects of apyrase and, consequently, insulin secretion. These results were confirmed using the P1-CGS15943 receptor antagonist $[19,20]$.

The activity of NTPDase3 in humans has been demonstrated only on Langerhans islet cells of the pancreas: $\alpha, \beta, \delta$ and PP cells $[11,67]$. The presence of NTPDase3 on $\beta$-cells suggests that this enzyme may affect insulin secretion by participating in the hydrolysis of adenine nucleotides, and thereby affect the activation of P2 receptors. Animal studies have confirmed that this process is possible [11]. The studies by Jacques-Silva in humans have shown that the ecto-nucleotidase inhibitor ARL 67156 markedly increases insulin secretion at low blood glucose levels $[19,20]$. Monoclonal antibodies were used as the specific inhibitor of human NTPDase3 in experimental studies [68].

Presumably, the decrease in ecto-5'-nucleotidase activity should result in an increase in extracellular adenosine level, which may affect insulin secretion [69]. Basal micromolar concentration of adenosine in isolated pancreatic islets is sufficient to stimulate secretion of glucagon and inhibit insulin secretion by $A_{1}$ receptor activation $[14,70]$.

\section{The role of cytokines in $\beta$-cell function disorders}

The mechanism of pancreatic islet cell disorders is different in type 1 and type 2 diabetes. In type 1 diabetes, a decrease in insulin production is caused by progressive damage of $\beta$-cells by autoimmune apoptosis, and the process involves proinflammatory cytokines [71, 72]. In type 2 diabetes, $\beta$-cell dysfunction and progressive decline in the number of these cells is accompanied by an increase in blood levels of cytokines, chemokines and free fatty acids and chronic hyperglycaemia [72, 73]. In type 2 diabetes, 
the adipose tissue releases free fatty acids, hormones, and cytokines. Moreover, free fatty acids also contribute to an increase in the release of cytokines such as IL- $1 \beta$, IL-6 and IL-8 [73]. Chronic exposure of $\beta$-cells to these compounds causes excessive formation and release of reactive oxygen species and the activation of caspases. These processes lead to inhibition of insulin secretion and promote apoptosis of pancreatic $\beta$-cells [72].

The involvement of proinflammatory cytokines such as interleukin-1 $\beta$, tumour necrosis factor- $\alpha$ and interferon- $\gamma$ is well known in type 1 diabetes $[72,74]$. Elevated levels of these cytokines were found both in the blood and in the cells of the islets of Langerhans. In diabetes, the pancreas is infiltrated by some immune cells such as lymphocytes and macrophages, and these cells are also a source of proinflammatory cytokines $[72,74,75]$. In addition, adipose tissue is an important source of cytokines. Cytokines produced and released from adipose tissue are termed adipocytokines [72, 76]. These compounds are divided into adipocytespecific cytokines such as leptin, resistin, adiponectin, visfatin and omentin, and non-specific cytokines such as IL- $1 \beta$, IL- 6 and TNF- $\alpha[72,76,77]$. Recently, the presence of a protein with a cytokine-like structure called pancreas-derived factor (PANDER) has been detected on pancreatic cells. It is believed that this protein is involved in apoptosis of $\beta$-cells $[78,79]$. Among the secreted cytokines are proapoptotic and proinflammatory compounds such as IL- $1 \beta$, TNF- $\alpha$, IFN- $\gamma$ and resistin, which also inhibit insulin secretion, as well as $\beta$-cell-protective compounds such as adiponectin and visfatin. Thus, in the course of diabetes, the balance between the amount of proinflammatory and protective cytokines is impaired against the protective cytokines due to increased production and secretion of proinflammatory cytokines.

\section{IL-1 $\beta$}

$\mathrm{IL}-1 \beta$ is one of the most important proinflammatory and proapoptotic cytokines responsible for $\beta$-cell dysfunction and is closely related to the pathogenesis of type 2 diabetes. IL- $1 \beta$ activity is dependent on caspase 1 , which is released from adipocytes by free fatty acids [73]. The effect of IL- $1 \beta$ on $\beta$-cells is a decrease in insulin secretion and in the number of pancreatic $\beta$-cells [80]. It is believed that there is a close relationship between inflammatory processes and the occurrence of insulin resistance, which determines the development of type 2 diabetes in the future $[3,7,81-83]$. The auto-inflammatory processes of the pancreas are caused not only by IL- $1 \beta$, but also by glucose itself, free fatty acids and leptin [80].

In $\beta$-pancreatic cells, IL- $1 \beta$ affects two metabolic pathways. On the one hand, it activates mitogen-acti- vated protein kinases (MAPKs), including extracellular signal-regulated kinase (ERK), and on the other hand, it affects the nuclear factor kappa-light-chain-enhancer of activated $\mathrm{B}$ cells (NF- $\kappa \mathrm{B}$ ) [84]. NF- $\kappa \mathrm{B}$ is a protein complex acting as a transcription factor. It occurs in almost all cells involved in the cellular response to stimuli such as stress, cytokines, free radicals, or antigens. Both pathways are necessary for the expression of the inducible nitric oxide synthase gene (iNOS), which, along with IL- $1 \beta$, is involved in the $\beta$-cell death process [84]. Chronic activation of NF- $\kappa$ B causes a sustained decrease in expression of $\beta$-cell-specific proteins such as insulin, glucose transporter 2 (GLUT-2), pancreatic and duodenal homeobox 1 (PDX-1), which coincides with the increase in iNOS activity [72]. Nitric oxide synthase is an enzyme involved in the synthesis of nitric oxide (II) from the nitrogen residue of L-arginine in the presence of NADPH and molecular oxygen. This enzyme is present on the cells of the immune and cardiovascular systems. Compounds such as sulphoraphane, radix clematidis extract, guggulsterone and others protect $\beta$-cells from cytokine-induced apoptosis (IL-1 $\beta$, IFN- $\gamma$ ) by inhibiting NF- $\kappa$ B activation and iNOS expression [85-87].

In humans, administration of an IL-1 receptor antagonist (IL-1Ra) inhibits the expression of proinflammatory factors, whose release is mediated by free fatty acids [73]. It is suspected that administration of an IL- $1 \beta$ receptor antagonist or IL- $1 \beta$ neutralizing antibody may diminish inflammatory processes of the pancreas and thereby reduce disorders of insulin production and secretion $[73,80,82,83]$.

Another potential mechanism of induction of pancreatic $\beta$-cell apoptosis by IL- $1 \beta$ and IFN- $\gamma$ is damage to the endoplasmic reticulum (ER) by influencing the $\mathrm{Ca}^{2+}$ pump [88]. Maedler et al. have shown that incubation for 20 hours of human pancreatic cells at high glucose concentrations results in a significant increase in IL- $1 \beta$ production by $\beta$-cells [89]. These observations suggest the involvement of IL- $1 \beta$ in the $\beta$-cell glucotoxicity process.

Hope for a new treatment for type 2 diabetes was offered by the study of Osborn et al [90]. The authors administered IL-1 $\beta$ antibodies to animals. After 13 weeks of treatment with the antibodies, decrease in glycated haemoglobin, serum proinsulin and insulin levels as well as reduction in pancreatic islet size were observed. Neutralization of IL-1 $\beta$ also resulted in significant reductions in serum amyloid A (SAA), which can be considered as a marker of pancreatic inflammation [90].

Another potential treatment for patients with diabetes is the administration of an IL-1 receptor antagonist [75, 91-93]. Studies on animal have shown that the administration of an IL-1 receptor antagonist 
in animals reduces the in vitro release of proinflammatory cytokines and chemokines [75]. In vivo studies showed that administration of IL-1 receptor antagonist reduced hyperglycaemia, decreased proinsulin/insulin ratio and improved insulin sensitivity [75]. Additionally, a reduction of secretion proinflammatory chemokines and cytokines, e.g. IL-1 $\beta$, IL-6, TNF- $\alpha$, was observed [75]. Also, in patients type 2 diabetes, administration of the recombinant IL-1 receptor antagonist anakinra resulted in significant reductions in glycated haemoglobin, fasting plasma glucose, proinsulin/insulin ratio and IL-6 blood levels $[82,91]$. However, insulin resistance remained unchanged [91].

\section{TNF- $\alpha$ and IFN- $\gamma$}

The mechanism of action of TNF- $\alpha$ and IFN- $\gamma$ in the apoptosis of Langerhans islet cells has not been fully explained [94]. It is well known that TNF- $\alpha$ and IFN- $\gamma$ induce apoptosis of $\beta$-cells and show synergistic effects in this regard by activation of $\mathrm{Ca}^{2+}$ calcium channels leading to mitochondrial dysfunction and caspase activation [95]. The process of death of $\beta$-cells involving these cytokines is mediated by interferon regulator factor 1 (IRF-1). X chromosome-linked inhibitor of XIAP (X-XIAP), an anti-apoptotic protein, protects $\beta$-cells against the harmful effects of TNF- $\alpha$ and IFN- $\gamma$ [72].

In patients with type 2 diabetes, elevated blood TNF- $\alpha$ levels were found $[71,96]$. In animals, adipocyte production of TNF- $\alpha$ has been shown to induce inflammatory processes, which is the background of insulin resistance in type 2 diabetes [8, 97]. Steinberg et al. have shown that activation of TNF receptor (TNFR) on skeletal muscle cells by TNF- $\alpha$ reduces 5'AMP-activated protein kinase (AMPK) activity through increased activity of protein phosphatase 2C (PP2C), which may be one of the reasons for insulin resistance [97]. This process, in turn, in vitro and in vivo, lowers the phosphorylation of acetyl-CoA carboxylase (ACC), and then inhibits fatty acid oxidation, increases the storage of diacylglycerol (DAG) in skeletal muscles and enhances insulin resistance [97]. The increase in TNF- $\alpha$ coexists especially with obesity. Metformin, a drug used in the treatment of diabetes, indirectly causes an increase in AMPK activity, resulting in increased glucose uptake by skeletal muscle cells and an increase in fatty acid oxidation in the mitochondria. IFN- $\gamma$ increases the expression of pancreatic-derived factor, which indicates that this cytokine also participates in the pathogenesis of diabetes and contributes to the death of $\beta$-cells [98].

\section{IL-6}

The role of IL-6 in inducing inflammatory processes is ambiguous. There are reports of its pro-inflammatory and protective effects. Intleukin- 6 levels have been shown to be elevated in patients with type 1 and type 2 diabetes [71, 99, 100]. In healthy people, blood levels of IL-6 are less than $5 \mathrm{pg} / \mathrm{mL}$ [99]. Different cells are capable of producing and releasing IL-6; however, adipose tissue is responsible for the release of approximately $10-35 \%$ of peripheral blood IL-6 concentration. Immune cells, especially macrophages that are present in adipose tissue, are responsible for the release of most IL-6, as well as TNF- $\alpha$ and IL- $1 \beta$ [101]. This cytokine plays an important role in regulating the balance between interleukin-17 (IL-17), involved in the formation of Th17 cells, and regulatory $T$ cells (Treg) [102]. Ryba-Stanisławowska et al. have confirmed the involvement of IL- 6 in the regulation of the balance between Th17 and Treg cells in peripheral blood in patients with type 1 diabetes, which is accompanied by elevated serum IL-6 levels [103]. The increase in blood IL- 6 coincides with the increase in glucose levels in people with type 2 diabetes. In particular, sudden hyperglycaemia increases the concentration of this cytokine in the blood [6]. Because oscillatory hyperglycaemia is more toxic to vascular endothelium than continuous hyperglycaemia, it is suspected that high levels of IL- 6 may be a risk factor for the development of atherosclerosis [6]. The effect of long-term hyperglycaemia is multiplied by oscillatory glucose levels and amplified by impaired glucose tolerance status. Antioxidant, glutathione, protects against elevated serum cytokine levels induced by hyperglycaemia [6]. This may indicate that hyperglycaemia is an important cause of oxidative stress in diabetes.

\section{Pancreatic-derived factor (PANDER)}

PANcreatic-DERived factor (PANDER) considered as a cytokine is present in the secretory follicles in pancreas [104]. In humans, PANDER is involved in apoptosis of $\alpha$ - and $\beta$-cells $[78,79]$, depending on concentration. It is believed that PANDER expression is influenced by insulin resistance and hyperglycaemia [79]. Chronic exposure of $\beta$-cells to saturated fatty acids such as palmitic acid (PA) leads to their apoptosis by activating the c-Jun N-terminal kinase (JNK) metabolic pathways [104]. Prolonged exposure of pancreatic cells to palmitic acid results in increased expression of PANDER, significant increase in phosphorylation of JNK, and activation of caspase 3 [104]. Studies by Xiang et al. have demonstrated a decrease in expression of PANDER [104] following administration of a specific inhibitor of JNK kinase (SP600125). Recently, PANDER expression in hepatocytes has been demonstrated in humans [79]. PANDER binding to liver cell membrane induces insulin resistance and increased gluconeogenesis [79]. Inactivation of hepatic PANDER in mice significantly reduced 
liver steatosis, insulin resistance and hyperglycaemia [79]. The association between secretion of this cytokine and the purinergic signalling is unknown.

\section{Summary}

In diabetes, metabolic disorders affect not only the pancreas, but also other organs such as the liver, skeletal muscles and adipose tissue. Key pathophysiological disorders are abnormal metabolism and glucose transport associated with inadequate insulin secretion. This leads to an increase in blood glucose (hyperglycaemia), the formation of free fatty acids and the release of proinflammatory cytokines. In type 2 diabetes, these processes involving purines and proinflammatory cytokines result in insulin resistance, which is the most important factor responsible for the progression of the disease. $\mathrm{P} 1$ and $\mathrm{P} 2$ receptors are present on cells in pancreatic islets, the liver and adipose tissue as well as in the cardiovascular system and pancreatic nerves. In humans, the $\mathrm{P} 2 \mathrm{X}_{3}$ receptor present on $\beta$-cells is of particular importance, because its activation by ATP generates a positive autocrine signal, resulting in insulin secretion $[19,20]$. In response to rapid decrease in blood glucose, ATP is released from the granules of $\beta$-cells together with insulin. Currently, we do not know the effects of activation of other $\mathrm{P} 2 \mathrm{X}$ receptors in diabetes, especially $P 2 Y$ receptors. Adenosine and $P 1\left(A_{1}\right.$ and $\left.A_{2 B}\right)$ receptors, which are present on adipocytes and pancreatic islet cells, play a significant role in the pathogenesis of diabetes. Adenosine is known to inhibit insulin secretion and stimulate the release of glucagon, which proves that $\alpha$-cells are more sensitive to adenosine than $\beta$-cells. Experimental studies on animals have shown that administration of $A_{1}$ receptor agonists results in normalization of blood glucose, decreased levels of free fatty acids and triglycerides, and increased insulin sensitivity [40]. By activating the $A_{1}$ receptor, adenosine inhibits lipolysis in adipocytes and reduces the release of free fatty acids. It is therefore expected that adenosine or its analogues may in the future be used for the treatment of dyslipidaemia and insulin resistance. Unfortunately, most adenosine analogues have significant side effects that result from the activation of $A_{1}$ receptors present in the heart and blood vessels, the most severe of which are hypotension and bradycardia, which limits their use in treatment. Adenosine activates $A_{2 B}$ receptors by increasing the production of IL- 6 and other cytokines and thereby contributes to increased insulin resistance. $A_{2 B}$ adenosine receptors are involved in macrophage activation, which affects the inflammatory process in adipose tissue and the development of insulin resistance. Adenosine affects muscle contraction-stimulated and insulin-stimulated glucose transport by reducing the amount of glucose transporters (GLUT4) on the cell surface, which results in lowering the effectiveness of insulin in glucose transport into skeletal muscle cells and adipocytes and contributes to the development of insulin resistance. We believe that compounds that affect the activity of enzymes such as adenosine deaminase and adenosine kinase as well as $A_{2 B}$ receptor antagonists may be effective therapeutic agents for increasing the sensitivity of insulin tissues. The activity of enzymes involved in the transformation of nucleotides has been demonstrated in cells of the pancreas and also in blood vessels. Among NTPDases the most important role is attributed to NTPDase3, whose activity has been shown exclusively on Langerhans islet cells. This enzyme may affect the secretion of insulin by participating in the hydrolysis of adenine nucleotides. Experimental studies have shown that the ecto-nucleotidase inhibitor ARL 67156 causes a marked increase in insulin secretion at low blood glucose. We suppose that similar effect can be achieved using monoclonal antibodies as a specific inhibitor of human NTPDase3. Activity of 5'-nucleotidase has not been demonstrated on pancreatic islet cells, only on the capillaries of Langerhans islets, and the effect of this enzyme on insulin secretion is not known.

In diabetes, the production and release of proinflammatory cytokines increases, resulting in increased levels of these cytokines both in the blood and in pancreatic islets. This leads to imbalance between the amount of proinflammatory and protective cytokines. Proinflammatory cytokines such as IL- $1 \beta$, TNF- $\alpha$ and IFN- $\gamma$ as well as PANDER are involved in apoptosis of pancreatic $\beta$-cells. The source of proinflammatory cytokines are macrophages migrating to pancreatic islet cells and adipocytes of fatty tissue. Interleukin- $1 \beta$ is the most potent proapoptotic and proinflammatory cytokine. Inside the $\beta$-cell, it activates mitogen-activated protein kinases (MAPKs), including extracellular signalregulated kinase (ERK), and affects the nuclear factor kappa-light-chain-enhancer of activated B cells (NF- $\kappa$ B). It is supposed that inhibition of NF- $\kappa$ B activity and iNOS expression may prove to be an effective way to protect pancreatic $\beta$-cells from apoptosis induced by IL- $1 \beta$ and other cytokines. Compounds such as sulphoraphane, radix clematidis extract, guggulsterone and others protect $\beta$-cells from cytokine-induced apoptosis (IL$-1 \beta$, IFN $-\gamma$ ) by inhibiting NF- $\kappa \mathrm{B}$ activation and iNOS expression. The hope for a new treatment for type 2 diabetes is the administration of anti-IL- $1 \beta$ antibodies and IL-1 receptor antagonists, which can diminish pancreatic inflammatory processes [82]. Presumably, inactivation of pancreatic-derived factor in patients with diabetes may reduce liver steatosis, insulin re- 
sistance and hyperglycaemia. TNF- $\alpha$ and IFN- $\gamma$ act synergistically to induce $\beta$-cell apoptosis. Reducing the concentration of these cytokines should result in suppression of inflammatory processes, normalization of blood glucose and reduced insulin resistance. In type 2 diabetes and obesity, particularly harmful is long-term elevation of IL-6 level, leading to chronic and sustained increase in SOCS3 expression. From a therapeutic point of view, it is advisable to keep the IL- 6 concentration below $5 \mathrm{pg} / \mathrm{mL}$ [99].

\section{REFERENCES}

1. Burnstock G, Novak I. Purinergic signalling and diabetes. Purinergic Signal. 2013; 9(3): 307-324, doi: 10.1007/s11302-013-9359-2, indexed in Pubmed: 23546842.

2. Burnstock $G$. Purinergic signalling in endocrine organs. Purinergic Signal. 2013; 9(3): 307-324, doi: 10.1007/s11302-013-9359-2, indexed in Pubmed: 23546842.

3. Memon AA, Sundquist J, Wang $X$, et al. The association between cytokines and insulin sensitivity in Iraqi immigrants and native Swedes. BMJ Open. 2013; 3(11): e003473, doi: 10.1136/bmjopen-2013-003473, indexed in Pubmed: 24293202.

4. Asakawa H, Miyagawa J, Hanafusa T, et al. High glucose and hyperosmolarity increase secretion of interleukin-1 beta in cultured human aortic endothelial cells. J Diabetes Complications. 1997; 11(3): 176-179, indexed in Pubmed: 9174899.

5. Harding HP, Ron D. Endoplasmic reticulum stress and the development of diabetes: a review. Diabetes. 2002; 51 Suppl 3: S455-S461, indexed in Pubmed: 12475790.

6. Esposito K, Nappo F, Marfella R, et al. Inflammatory cytokine concentrations are acutely increased by hyperglycemia in humans: role of oxidative stress. Circulation. 2002; 106(16): 2067-2072, indexed in Pubmed: 12379575.

7. Weir GC, Bonner-Weir S. Five stages of evolving beta-cell dysfunction during progression to diabetes. Diabetes. 2004; 53 Suppl 3: S16-S21, indexed in Pubmed: 15561905.

8. Hotamisligil GS, Shargill NS, Spiegelman BM. Adipose expression of tumor necrosis factor-alpha: direct role in obesity-linked insulin resistance. Science. 1993; 259(5091): 87-91, indexed in Pubmed: 7678183.

9. Hotamisligil GS. Role of endoplasmic reticulum stress and c-Jun $\mathrm{NH} 2$-terminal kinase pathways in inflammation and origin of obesity and diabetes. Diabetes. 2005; 54 Suppl 2: S73-S78, indexed in Pubmed: 16306344.

10. Böcx P. Fate of ATP in secretory granules: Phosphohydrolase studies in pancreatic vascular bed. Archives of Histology and Cytology. 1989; 52(Suppl): 85-90, doi: 10.1679/aohc.52.suppl_85.

11. Lavoie EG, Fausther M, Kauffenstein G, et al. Identification of the ectonucleotidases expressed in mouse, rat, and human Langerhans islets: potential role of NTPDase 3 in insulin secretion. Am J Physiol Endocrinol Metab. 2010; 299(4): E647-E656, doi: 10.1152/ajpendo.00126.2010, indexed in Pubmed: 20682839.

12. Burnstock G, Novak I. Purinergic signalling in the pancreas in health and disease. J Endocrinol. 2012; 213(2): 123-141, doi: 10.1530/JOE-11-0434, indexed in Pubmed: 22396456.

13. Wang C, Geng B, Cui Q, et al. Intracellular and extracellular adenosine triphosphate in regulation of insulin secretion from pancreatic $\beta$ cells $(\beta)$. J Diabetes. 2014; 6(2): 113-119, doi: 10.1111/1753-0407.12098, indexed in Pubmed: 24134160.

14. Chapal J, Loubatières-Mariani MM, Petit $P$, et al. Evidence for an A2-subtype adenosine receptor on pancreatic glucagon secreting cells. Br J Pharmacol. 1985; 86(3): 565-569, indexed in Pubmed: 2998522.

15. Rodrigue-Candela JL, Martin-Hernandez D, Castilla-Cortazar T. Stimulation of insulin secretion in vitro by adenosine triphosphate. Nature. 1963: 197: 1304, indexed in Pubmed: 13974649.
16. Squires $P E$, James $R F$, London $N J$, et al. ATP-induced intracellular $\mathrm{Ca} 2+$ signals in isolated human insulin-secreting cells. Pflugers Arch. 1994; 427(1-2): 181-183, indexed in Pubmed: 8058469.

17. Petit $P$, Lajoix $A D$, Gross R. $P 2$ purinergic signalling in the pancreatic beta-cell: control of insulin secretion and pharmacology. Eur J Pharm Sci. 2009; 37(2): 67-75, doi: 10.1016/j.ejps.2009.01.007, indexed in Pubmed: 19429412.

18. Santini E, Cuccato $S$, Madec $S$, et al. Extracellular adenosine 5 '-triphosphate modulates insulin secretion via functionally active purinergic receptors of $X$ and $Y$ subtype. Endocrinology. 2009; 150(6): 2596-2602, doi: 10.1210/en.2008-1486, indexed in Pubmed: 19196799.

19. Jacques-Silva MC, Cabrera O, Makeeva N, et al. Endogenously relesed ATP serves as a positive autocrine feedback loop for the human pancreatic beta cell. Purinergic Signal. 2008; 4: S49.

20. Jacques-Silva MC, Correa-Medina M, Cabrera O, et al. ATP-gated $\mathrm{P} 2 \mathrm{X} 3$ receptors constitute a positive autocrine signal for insulin release in the human pancreatic beta cell. Proc Natl Acad Sci U S A. 2010; 107(14): 6465-6470, doi: 10.1073/pnas.0908935107, indexed in Pubmed: 20308565.

21. Lugo-Garcia L, Nadal B, Gomis R, et al. Human pancreatic islets express the purinergic $\mathrm{P} 2 \mathrm{Y} 11$ and $\mathrm{P} 2 \mathrm{Y} 12$ receptors. Horm Metab Res. 2008; 40(11): 827-830, doi: 10.1055/s-0028-1082050, indexed in Pubmed: 18726826.

22. Tahani HM. The purinergic nerve hypothesis and insulin secretion. Z Ernahrungswiss. 1979; 18(2): 128-138, indexed in Pubmed: 43035.

23. Leitner JW, Sussman KE, Vatter AE, et al. Adenine nucleotides in the secretory granule fraction of rat islets. Endocrinology. 1975; 96(3): 662-677, doi: 10.1210/endo-96-3-662, indexed in Pubmed: 163731.

24. Loubatières-Mariani MM, Loubatières AL, Chapal J, et al. [Adenosine triphosphate (ATP) and glucose. Action on insulin and glucagon secretion]. C R Seances Soc Biol Fil. 1976; 170(4): 833 836, indexed in Pubmed: 137051.

25. Karanauskaite J, Hoppa MB, Braun M, et al. Quantal ATP release in rat beta-cells by exocytosis of insulin-containing LDCVs. Pflugers Arch. 2009; 458(2): 389-401, doi: 10.1007/s00424-008-0610-6, indexed in Pubmed: 19018564.

26. Fernandez-Alvarez J, Hillaire-Buys D, Loubatières-Mariani MM, et al. P2 receptor agonists stimulate insulin release from human pancreatic islets. Pancreas. 2001; 22(1): 69-71, indexed in Pubmed: 11138974.

27. Stam NJ, Klomp J, Van de Heuvel N, et al. Molecular cloning and characterization of a novel orphan receptor (P2P) expressed in human pancreas that shows high structural homology to the P2U purinoceptor. FEBS Lett. 1996; 384(3): 260-264, indexed in Pubmed: 8617367

28. Ohtani M, Suzuki J, Jacobson KA, et al. Evidence for the possible involvement of the $\mathrm{P} 2 \mathrm{Y}(6)$ receptor in $\mathrm{Ca}(2+)$ mobilization and insulin secretion in mouse pancreatic islets. Purinergic Signal. 2008; 4(4): 365-375, doi: 10.1007/s11302-008-9122-2, indexed in Pubmed: 18784987.

29. Parandeh F, Abaraviciene SM, Amisten S, et al. Uridine diphosphate (UDP) stimulates insulin secretion by activation of P2Y6 receptors. Biochem Biophys Res Commun. 2008; 370(3): 499-503, doi: 10.1016/j.bbrc.2008.03.119, indexed in Pubmed: 18387359.

30. Amisten S, Meidute-Abaraviciene $S$, Tan $C$, et al. ADP mediates inhibition of insulin secretion by activation of $\mathrm{P} 2 \mathrm{Y} 13$ receptors in mice. Diabetologia. 2010; 53(9): 1927-1934, doi: 10.1007/ s00125-010-1807-8, indexed in Pubmed: 20526761.

31. Léon C, Freund M, Latchoumanin O, et al. The P2Y(1) receptor is involved in the maintenance of glucose homeostasis and in insulin secretion in mice. Purinergic Signal. 2005; 1(2): 145-151, doi: 10.1007/s11302-005-6209-x, indexed in Pubmed: 18404499.

32. Fredholm BB, IJzerman AP, Jacobson KA, et al. International Union of Basic and Clinical Pharmacology. LXXXI. Nomenclature and classification of adenosine receptors - an update. Pharmacol Rev. 2011; 63(1): 1-34, doi: 10.1124/pr.110.003285, indexed in Pubmed: 21303899. 
33. Rüsing $D$, Müller $C E$, Verspohl EJ. The impact of adenosine and $\mathrm{A}(2 \mathrm{~B})$ receptors on glucose homoeostasis. J Pharm Pharmacol. 2006; 58(12): 1639-1645, doi: 10.1211/jpp.58.12.0011, indexed in Pubmed: 17331328.

34. Johansson SM, Salehi A, Sandström ME, et al. A1 receptor deficiency causes increased insulin and glucagon secretion in mice. Biochem Pharmacol. 2007; 74(11): 1628-1635, doi: 10.1016/j. bcp.2007.08.006, indexed in Pubmed: 17869224.

35. Tudurí E, Filiputti E, Carneiro EM, et al. Inhibition of $\mathrm{Ca} 2+$ signaling and glucagon secretion in mouse pancreatic alpha-cells by extracellular ATP and purinergic receptors. Am J Physiol Endocrinol Metab. 2008; 294(5): E952-E960, doi: 10.1152/ajpendo.00641.2007, indexed in Pubmed: 18349114.

36. Salehi A, Parandeh F, Fredholm BB, et al. Absence of adenosine A1 receptors unmasks pulses of insulin release and prolongs those of glucagon and somatostatin. Life Sci. 2009; 85(11-12): 470-476, doi: 10.1016/j.Ifs.2009.08.001, indexed in Pubmed: 19682463.

37. Yang GK, Fredholm BB, Kieffer TJ, et al. Improved blood glucose disposal and altered insulin secretion patterns in adenosine $A(1)$ receptor knockout mice. Am J Physiol Endocrinol Metab. 2012; 303(2): E180-E190, doi: 10.1152/ajpendo.00050.2012, indexed in Pubmed: 22550063.

38. WEIR G, KNOWLTON S, MARTIN D. Nucleotide and Nucleoside Stimulation of Glucagon Secretion. Endocrinology. 1975; 97(4): 932-936, doi: 10.1210/endo-97-4-932.

39. Ismail NA, El Denshary EE, Montague W. Adenosine and the regulation of insulin secretion by isolated rat islets of Langerhans. Biochem J. 1977; 164(2): 409-413, indexed in Pubmed: 328013.

40. Töpfer $M$, Burbiel CE, Müller CE, et al. Modulation of insulin release by adenosine $A 1$ receptor agonists and antagonists in INS-1 cells: the possible contribution of $86 \mathrm{Rb}+$ efflux and $45 \mathrm{Ca} 2+$ uptake. Cell Biochem Funct. 2008; 26(8): 833-843, doi: 10.1002/ /cbf.1514, indexed in Pubmed: 18979526.

41. Dhalla AK, Chisholm JW, Reaven GM, et al. A1 adenosine receptor: role in diabetes and obesity. Handb Exp Pharmacol. 2009(193): 271-295, doi: 10.1007/978-3-540-89615-9_9, indexed in Pubmed: 19639285.

42. Fain JN, Pointer RH, Ward WF. Effects of adenosine nucleosides on adenylate cyclase, phosphodiesterase, cyclic adenosine monophosphate accumulation, and lipolysis in fat cells. J Biol Chem. 1972; 247(21): 6866-6872, indexed in Pubmed: 4343159.

43. DOLE VP. Effect of nucleic acid metabolites on lipolysis in adipose tissue. J Biol Chem. 1961; 236: 3125-3130, indexed in Pubmed: 13886990.

44. Schwabe U, Ebert R, Erbler HC. Adenosine release from isolated fat cells and its significance for the effects of hormones on cyclic 3',5'-AMP levels and lipolysis. Naunyn Schmiedebergs Arch Pharmacol. 1973; 276(2): 133-148, indexed in Pubmed: 4351791.

45. Schwabe $U$, Ebert R. Stimulation of cyclic adenosine $3^{\prime}, 5^{\prime}$-monophosphate accumulation and lipolysis in fat cells by adenosine deaminase. Naunyn Schmiedebergs Arch Pharmacol. 1974; 282(1): 33-44, indexed in Pubmed: 4365633.

46. Cheng JT, Chi TC, Liu IM. Activation of adenosine A1 receptors by drugs to lower plasma glucose in streptozotocin-induced diabetic rats. Auton Neurosci. 2000; 83(3): 127-133, doi: 10.1016/S01651838(00)00106-5, indexed in Pubmed: 11593763.

47. Ma L, Mao SL, Taylor KL, et al. Prevention of obesity and insulin resistance in mice lacking plasminogen activator inhibitor 1. Diabetes. 2004; 53(2): 336-346, indexed in Pubmed: 14747283.

48. Csoka B, Koscso B, Toro G, et al. A2B Adenosine Receptors Prevent Insulin Resistance by Inhibiting Adipose Tissue Inflammation via Maintaining Alternative Macrophage Activation. Diabetes. 2013; 63(3): 850-866, doi: $10.2337 / \mathrm{db} 13-0573$.

49. Linden J. New insights into the regulation of inflammation by adenosine. J Clin Invest. 2006; 116(7): 1835-1837, doi: 10.1172/ $/ \mathrm{JCl} 29125$, indexed in Pubmed: 16823484.

50. Ryzhov S, Zaynagetdinov R, Goldstein AE, et al. Effect of A2B adenosine receptor gene ablation on proinflammatory adenosine signaling in mast cells. J Immunol. 2008; 180(11): 7212-7220, indexed in Pubmed: 18490720.

51. Nieto-Vazquez I, Fernández-Veledo S, de Alvaro C, et al. Dual role of interleukin- 6 in regulating insulin sensitivity in murine skeletal muscle. Diabetes. 2008; 57(12): 3211-3221, doi: 10.2337/db071062, indexed in Pubmed: 18796617.
52. Sarvas JL, Khaper N, Lees SJ. The IL-6 Paradox: Context Dependent Interplay of SOCS3 and AMPK. J Diabetes Metab. 2013; Suppl 13, doi: 10.4172/2155-6156.S13-003, indexed in Pubmed: 24244888.

53. Ueki K, Kondo T, Kahn CR. Suppressor of cytokine signaling 1 (SOCS-1) and SOCS-3 cause insulin resistance through inhibition of tyrosine phosphorylation of insulin receptor substrate proteins by discrete mechanisms. Mol Cell Biol. 2004; 24(12): 5434-5446, doi: 10.1128/MCB.24.12.5434-5446.2004, indexed in Pubmed: 15169905.

54. Sochocka M. Rozpoznawanie patogenów przez wrodzony system odporności. Posteppy Hig Med Dow. 2008; 62: 676-687.

55. Challis RA, Budohoski L, McManus $B$, et al. Effects of an adenosine-receptor antagonist on insulin-resistance in soleus muscle from obese Zucker rats. Biochem J. 1984; 221(3): 915-917, indexed in Pubmed: 6383352.

56. Budohoski L, Challiss RA, Cooney GJ, et al. Reversal of dietaryinduced insulin resistance in muscle of the rat by adenosine deaminase and an adenosine-receptor antagonist. Biochem J. 1984; 224(1): 327-330, indexed in Pubmed: 6391473.

57. Figler RA, Wang G, Srinivasan S, et al. Links between insulin resistance, adenosine A2B receptors, and inflammatory markers in mice and humans. Diabetes. 2011; 60(2): 669-679, doi: 10.2337/ /db10-1070, indexed in Pubmed: 21270276.

58. Han DH, Hansen PA, Nolte LA, et al. Removal of adenosine decreases the responsiveness of muscle glucose transport to insulin and contractions. Diabetes. 1998; 47(11): 1671-1675, indexed in Pubmed: 9792534.

59. Kuroda M, Honnor RC, Cushman SW, et al. Regulation of insulin-stimulated glucose transport in the isolated rat adipocyte. cAMPindependent effects of lipolytic and antilipolytic agents. J Biol Chem. 1987; 262(1): 245-253, indexed in Pubmed: 3025204.

60. Robson SC, Sévigny J, Zimmermann H. The E-NTPDase family of ectonucleotidases: Structure function relationships and pathophysiological significance. Purinergic Signal. 2006; 2(2): 409-430, doi: 10.1007/s11302-006-9003-5, indexed in Pubmed: 18404480

61. Chia JSJ, McRae JL, Cowan PJ, et al. The CD39-adenosinergic axis in the pathogenesis of immune and nonimmune diabetes. J Biomed Biotechnol. 2012; 2012: 320495, doi: 10.1155/2012/320495, indexed in Pubmed: 23118504.

62. Lunkes GI, Lunkes D, Stefanello F, et al. Enzymes that hydrolyze adenine nucleotides in diabetes and associated pathologies. Thromb Res. 2003; 109(4): 189-194, indexed in Pubmed: 12757773.

63. Kittel A, Garrido M, Varga G. Localization of NTPDase1/CD39 in normal and transformed human pancreas. J Histochem Cytochem. 2002; 50(4): 549-556, doi: 10.1177/002215540205000412, indexed in Pubmed: 11897808.

64. Crack BE, Pollard CE, Beukers MW, et al. Pharmacological and biochemical analysis of FPL 67156, a novel, selective inhibitor of ecto-ATPase. Br J Pharmacol. 1995; 114(2): 475-481, indexed in Pubmed: 7533620.

65. Westfall TD, Kennedy C, Sneddon P. The ecto-ATPase inhibitor ARL 67156 enhances parasympathetic neurotransmission in the guinea-pig urinary bladder. Eur J Pharmacol. 1997; 329(2-3): 169-173, indexed in Pubmed: 9226410.

66. Lévesque SA, Lavoie EG, Lecka J, et al. Specificity of the ectoATPase inhibitor ARL 67156 on human and mouse ectonucleotidases. Br J Pharmacol. 2007; 152(1): 141-150, doi: 10.1038/ sj.bjp.0707361, indexed in Pubmed: 17603550.

67. Künzli BM, Berberat PO, Giese T, et al. Upregulation of CD39/ /NTPDases and P2 receptors in human pancreatic disease. Am J Physiol Gastrointest Liver Physiol. 2007; 292(1): G223-G230, doi: 10.1152/ajpgi.00259.2006, indexed in Pubmed: 16920697.

68. Munkonda MN, Pelletier J, Ivanenkov VV, et al. Characterization of a monoclonal antibody as the first specific inhibitor of human NTP diphosphohydrolase-3: partial characterization of the inhibitory epitope and potential applications. FEBS J. 2009; 276(2): 479-496, doi: 10.1111/j.1742-4658.2008.06797.x, indexed in Pubmed: 19120451.

69. Thompson LF, Eltzschig HK, Ibla JC, et al. Crucial role for ecto-5'-nucleotidase (CD73) in vascular leakage during hypoxia. J Exp Med. 2004; 200(11): 1395-1405, doi: 10.1084/jem.20040915, indexed in Pubmed: 15583013. 
70. Verspohl EJ, Johannwille B, Waheed A, et al. Effect of purinergic agonists and antagonists on insulin secretion from INS-1 cells (insulinoma cell line) and rat pancreatic islets. Can J Physiol Pharmacol. 2002; 80(6): 562-568, indexed in Pubmed: 12117305.

71. Pickup JC, Chusney GD, Thomas SM, et al. Plasma interleukin-6, tumour necrosis factor alpha and blood cytokine production in type 2 diabetes. Life Sci. 2000; 67(3): 291-300, indexed in Pubmed: 10983873.

72. Wang C, Guan Y, Yang J. Cytokines in the Progression of Pancreatic $\beta$-Cell Dysfunction. Int J Endocrinol. 2010; 2010: 515136, doi: 10.1155/2010/515136, indexed in Pubmed: 21113299.

73. Böni-Schnetzler M, Boller S, Debray S, et al. Free fatty acids induce a proinflammatory response in islets via the abundantly expressed interleukin-1 receptor I. Endocrinology. 2009; 150(12): 5218-5229, doi: 10.1210/en.2009-0543, indexed in Pubmed: 19819943.

74. Kawasaki E, Abiru N, Eguchi K. Prevention of type 1 diabetes: from the view point of beta cell damage. Diabetes Res Clin Pract. 2004; 66 Suppl 1: S27-S32, doi: 10.1016/j.diabres.2003.09.015, indexed in Pubmed: 15563975.

75. Ehses JA, Lacraz G, Giroix MH, et al. IL-1 antagonism reduces hyperglycemia and tissue inflammation in the type 2 diabetic GK rat. Proc Natl Acad Sci U S A. 2009; 106(33): 13998-14003, doi: 10.1073/pnas.0810087106, indexed in Pubmed: 19666548.

76. Ahima R. Adipose Tissue as an Endocrine Organ. Obesity. 2006; 14(5): 242-249, doi: 10.1038/oby.2006.317.

77. Bassols J, Ortega FJ, Moreno-Navarrete JM, et al. Study of the proinflammatory role of human differentiated omental adipocytes. J Cell Biochem. 2009; 107(6): 1107-1117, doi: 10.1002/ /jcb.22208, indexed in Pubmed: 19492335.

78. Yang J, Gao Z, Robert CE, et al. Structure-function studies of PANDER, an islet specific cytokine inducing cell death of insulinsecreting beta cells. Biochemistry. 2005; 44(34): 11342-11352, doi: 10.1021/bi0503908, indexed in Pubmed: 16114871.

79. Wang $C$, Burkhardt BR, Guan $Y$, et al. Role of pancreatic-derived factor in type 2 diabetes: evidence from pancreatic $\beta$ cells and liver. Nutr Rev. 2012; 70(2): 100-106, doi: 10.1111/j.17534887.2011.00457.x, indexed in Pubmed: 22300596.

80. Dinarello CA, Donath MY, Mandrup-Poulsen T. Role of IL-1 beta in type 2 diabetes. Curr Opin Endocrinol Diabetes Obes. 2010; 17(4): 314-321, doi: 10.1097/MED.0b013e32833bf6dc, indexed in Pubmed: 20588114.

81. Shoelson $S E$, Lee J, Goldfine AB. Inflammation and insulin resistance. J Clin Invest. 2006; 116(7): 1793-1801, doi: 10.1172/ $/ \mathrm{JCl} 29069$, indexed in Pubmed: 16823477.

82. Donath MY, Mandrup-Poulsen T. The use of interleukin-1-receptor antagonists in the treatment of diabetes mellitus. Nat Clin Pract Endocrinol Metab. 2008; 4(5): 240-241, doi: 10.1038/ncpendmet0783, indexed in Pubmed: 18317479.

83. Donath MY, Böni-Schnetzler M, Ellingsgaard H, et al. Cytokine production by islets in health and diabetes: cellular origin, regulation and function. Trends Endocrinol Metab. 2010; 21(5): 261-267, doi: 10.1016/j.tem.2009.12.010, indexed in Pubmed: 20096598.

84. Larsen CM, Faulenbach M, Vaag A, et al. Interleukin-1 receptor antagonist-treatment of patients with type 2 diabetes. Ugeskr Laeger. 2007; 169(45): 3868-3871, indexed in Pubmed: 18031661.

85. Kim EK, Song MY, Hwang TO, et al. Radix clematidis extract protects against cytokine- and streptozotocin-induced beta-cell damage by suppressing the NF-kappaB pathway. Int J Mol Med. 2008; 22(3): 349-356, indexed in Pubmed: 18698494.

86. Lv Na, Song MY, Kim EK, et al. Guggulsterone, a plant sterol, inhibits NF-kappaB activation and protects pancreatic beta cells from cytokine toxicity. Mol Cell Endocrinol. 2008; 289(1-2): 49-59, doi: 10.1016/j.mce.2008.02.001, indexed in Pubmed: 18343024.

87. Song MY, Kim EK, Moon WS, et al. Sulforaphane protects against cytokine- and streptozotocin-induced beta-cell damage by suppressing the NF-kappaB pathway. Toxicol Appl Pharmacol. 2009; 235(1): 57-67, doi: 10.1016/j.taap.2008.11.007, indexed in Pubmed: 19071154

88. Eizirik DL, Miani M, Cardozo AK. Signalling danger: endoplasmic reticulum stress and the unfolded protein response in pancreatic islet inflammation. Diabetologia. 2013; 56(2): 234-241, doi: 10.1007/s00125-012-2762-3, indexed in Pubmed: 23132339.

89. Maedler K, Sergeev P, Ris F, et al. Glucose-induced beta cell production of IL-1 beta contributes to glucotoxicity in human pancreatic islets. J Clin Invest. 2002; 110(6): 851-860, doi: 10.1172/JCI15318, indexed in Pubmed: 12235117.

90. Osborn O, Brownell SE, Sanchez-Alavez M, et al. Treatment with an Interleukin 1 beta antibody improves glycemic control in dietinduced obesity. Cytokine. 2008; 44(1): 141-148, doi: 10.1016/j. cyto.2008.07.004, indexed in Pubmed: 18723371.

91. Larsen L, Størling J, Darville M, et al. Extracellular signal-regulated kinase is essential for interleukin-1-induced and nuclear factor kappaB-mediated gene expression in insulin-producing INS-1E cells. Diabetologia. 2005; 48(12): 2582-2590, doi: 10.1007/ /s00125-005-0039-9, indexed in Pubmed: 16283237.

92. Lacraz G, Giroix MH, Kassis N, et al. Islet endothelial activation and oxidative stress gene expression is reduced by IL-1Ra treatment in the type 2 diabetic GK rat. PLoS One. 2009; 4(9): e6963, doi: 10.1371/journal.pone.0006963, indexed in Pubmed: 19742300.

93. Klueh U, Antar O, Qiao Yi, et al. Role of interleukin-1/interleukin-1 receptor antagonist family of cytokines in long-term continuous glucose monitoring in vivo. J Diabetes Sci Technol. 2013; 7(6): 1538-1546, doi: 10.1177/193229681300700614, indexed in Pubmed: 24351180.

94. Movahedi B, Van de Casteele M, Caluwé N, et al. Human pancreatic duct cells can produce tumour necrosis factor-alpha that damages neighbouring beta cells and activates dendritic cells. Diabetologia. 2004; 47(6): 998-1008, doi: 10.1007/s00125-0041426-3, indexed in Pubmed: 15184981.

95. Chang I, Cho N, Kim S, et al. Role of calcium in pancreatic islet cell death by IFN-gamma/TNF-alpha. J Immunol. 2004; 172(11): 7008-7014, indexed in Pubmed: 15153522

96. Chen $\mathrm{H}$, Ren An, Hu S, et al. The significance of tumor necrosis factor-alpha in newly diagnosed type 2 diabetic patients by transient intensive insulin treatment. Diabetes Res Clin Pract. 2007; 75(3): 327-332, doi: 10.1016/j.diabres.2006.07.001, indexed in Pubmed: 16930761.

97. Steinberg GR, Michell BJ, van Denderen BJW, et al. Tumor necrosis factor alpha-induced skeletal muscle insulin resistance involves suppression of AMP-kinase signaling. Cell Metab. 2006; 4(6): 465-474, doi: 10.1016/j.cmet.2006.11.005, indexed in Pubmed: 17141630 .

98. Xu W, Gao Z, Wu J, et al. Interferon-gamma-induced regulation of the pancreatic derived cytokine FAM $3 B$ in islets and insulin-secreting betaTC3 cells. Mol Cell Endocrinol. 2005; 240(1-2): 74-81, doi: 10.1016/j.mce.2005.05.010, indexed in Pubmed: 16006032.

99. Kado S, Nagase T, Nagata N. Circulating levels of interleukin-6, its soluble receptor and interleukin-6/interleukin- 6 receptor complexes in patients with type 2 diabetes mellitus. Acta Diabetol. 1999; 36(1-2): 67-72, indexed in Pubmed: 10436255.

100. Mirza S, Hossain M, Mathews C, et al. Type 2-diabetes is associated with elevated levels of TNF-alpha, IL-6 and adiponectin and low levels of leptin in a population of Mexican Americans: a crosssectional study. Cytokine. 2012; 57(1): 136-142, doi: 10.1016/j. cyto.2011.09.029, indexed in Pubmed: 22035595.

101. Fain JN, Madan AK, Hiler ML, et al. Comparison of the release of adipokines by adipose tissue, adipose tissue matrix, and adipocytes from visceral and subcutaneous abdominal adipose tissues of obese humans. Endocrinology. 2004; 145(5): 2273-2282, doi: 10.1210/en.2003-1336, indexed in Pubmed: 14726444.

102. Kimura A, Kishimoto T. IL-6: regulator of Treg/Th17 balance. Eur J Immunol. 2010; 40(7): 1830-1835, doi: 10.1002/eji.201040391, indexed in Pubmed: 20583029.

103. Ryba-Stanisławowska M, Skrzypkowska M, Myśliwska J, et al. The serum IL-6 profile and Treg/Th17 peripheral cell populations in patients with type 1 diabetes. Mediators Inflamm. 2013; 2013: 205284, doi: 10.1155/2013/205284, indexed in Pubmed: 23533301.

104. Xiang JN, Chen DL, Yang LY. Effect of PANDER in $\beta$ TC6-cell lipoapoptosis and the protective role of exendin-4. Biochem Biophys Res Commun. 2012; 421(4): 701-706, doi: 10.1016/j. bbrc.2012.04.065, indexed in Pubmed: 22542939. 